\title{
精細管周囲の平滑筋様細胞について
}

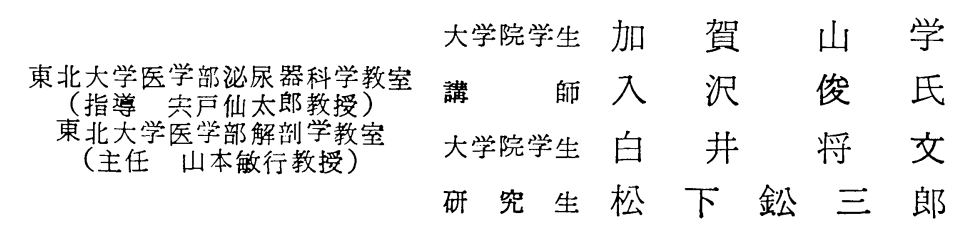

\section{CONTRACTILE CELLS IN THE BOUNDARY TISSUE OF SEMINIFEROUS TUBULES}

\author{
Manabu Kagayama, Shunshi Irisawa, Masahumi Shirai and Kozaburo Matsushita \\ Urological Clinic, Tohoku University School of Medicine, Sendai \\ (Director: Prof. S. Shishito and Prof. T. Yamamoto)
}

The existence of a contractile type of cells in the boundary tissue of seminiferous tubules has been ascertained by electron microscopy on the testes in rats, mice and dogs.

These cells are flattened to form a thin layer of cytoplasm around the seminiferous tubule. Distribution of cytoplasmic organelles such as granular ER, mitochondria and Golgi complex is confined within the central region of the cell body. The major peripheral portion of the cytoplasm is filled with numerous fine filaments, $<5 \mathrm{~m} \mu$ in thickness. Pinocytic vesicles and accumulations of dense substance are found immediately beneath the plasma membrane, outer surface of which is lined with thin basement membrane.

Thus, the fine structure of these cells shows some close similarities to that of smooth muscle cells and myo-epithelial cells.

\section{緒言}

精巣組織の中で, 精細管上皮における精子形成過程 や, 間質細胞については, すてに多数の電顥形態学的研 究が行われてているが, 精細管周囲を包む被膜組織につい ては，これまであまり報告がない. 電顕的知見の取り入 れられた最近の成書 ${ }^{1233) 4)}$ (执いても, 精細管周囲の被 膜は, 基底膜むふびそれを取り囲む結合組織性固有層か ら成るとされており，固有層内の細胞成分としては，線 維芽細胞のみが挙げられているに過ざな。

しかる汇最近一部の学者, たこえばClermont ${ }^{5)}$, Lacy and Rotblat ${ }^{6)}$, Leeson and Leeson ${ }^{7)}$ らはラットの, また Lacy ${ }^{8)}$ はラットおよびヒトの精細管被膜内に平滑 等様細胞つ存在を主張し, 本被膜が収縮能を持つであろ うと予測している。そこで我队はラット,マウスおよび イヌの精巣について, 平滑筋様細胞が存在するか否かを 確認するため, 電顕的観察を行つたので, とこにその結 果を報告する。

\section{観察材料および方法}

観察材料には成熟マウス,ラットおよびイヌを使用し
た.エーテル麻酔下に摘出した新鮮な精巣を, 両刃の 安全カミソリ刃で $2 \sim 3 \mathrm{~mm}^{3}$ の小組織片とし, 直ちに Millonig") の処方に従いpH7.4 に緩衝した $1 \%$ オスミ ウム酸等張液で $2 \sim 3$ 時間固定, エタノール系列にて脱 水ののち, Luft(10) のオ法によつて Epon 812 に包埋し た.超薄切片作製ば,ガラスナイフを用いてPorter-Blum 超ミクロトームにより行い，Millonigin ${ }^{11}$ の捨溶液, あ るい酢酸ウランの単染色，さたは両者の併用による二 重染色を施したのち, 日立HS- 6 型電子顥微鏡を用いて 直接倍率 $2,000 \sim 10,000$ 倍で観察し, 適宜写真的拡大 を行つた。

\section{覵察所見}

精細管上皮の基底面は，厚さ 100〜 200m $\mu$ の基底膜 によつて被われる. その周囲から精細管を包む被膜組織 は, 図 1 に示されるように 4 層すなわち精細管側より， 1）少量の繊細な膠原線維を含む細胞間胿，2）扁平細 胞層，3）少量の繊細な膠原線維を合む細胞間腔, およ び 4）線維芽細胞層の層状構成を示す.

精細管の横断切片で観察すると，第 2 層を形成する扁 

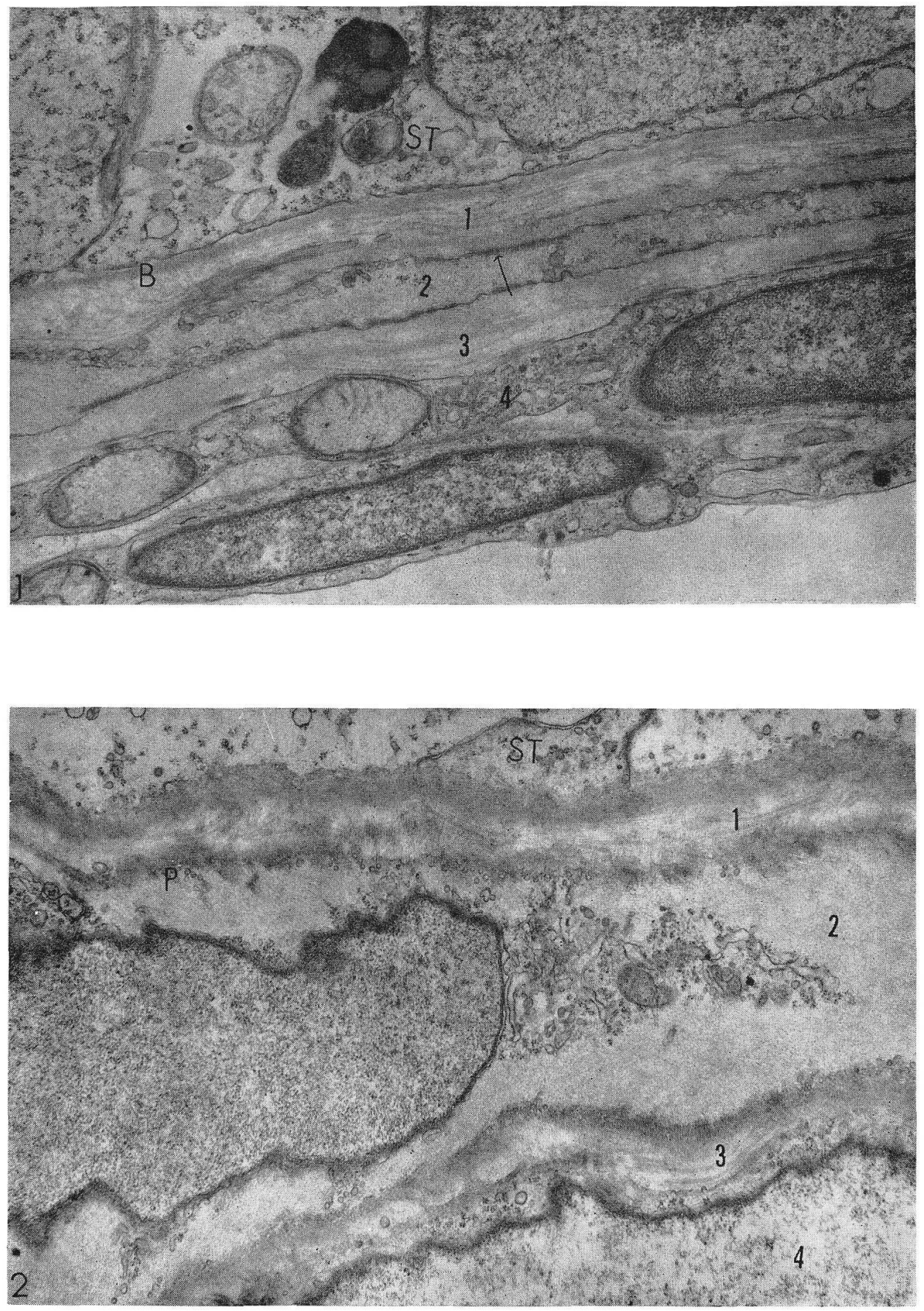

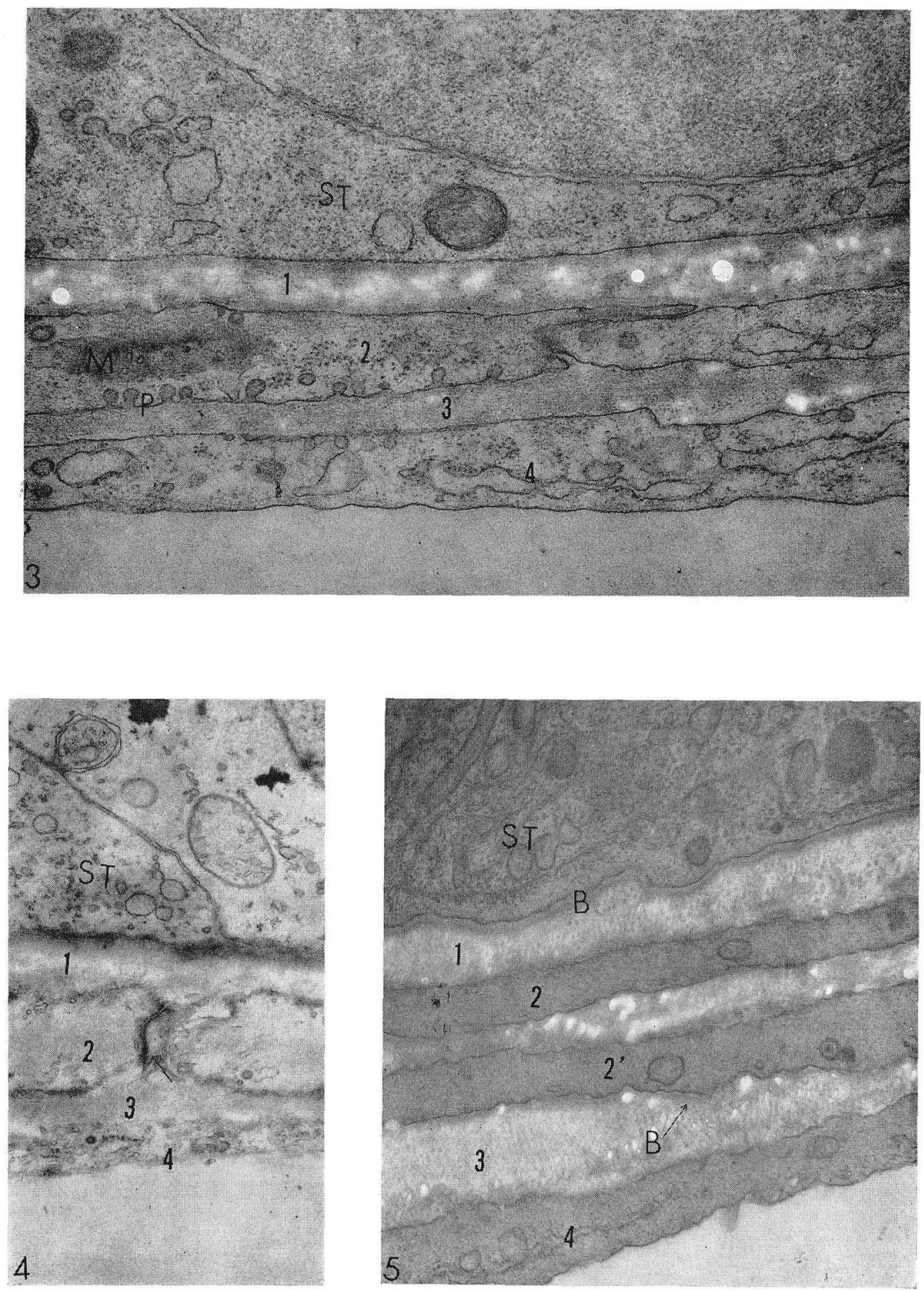
平細胞の断面は，1 層 (イメでは時に 2 層) の薄層をな して精細管の全周を完全に取り囲み，また内外両面より 細胞間腔に挟悉れ，それを隔てて内面は精細管上皮に， また外面は線維芽細胞に相対している. 本細胞が 2 層に 配列するときに注，両層の間に少量の膠原線維を含む間 隚が介在する．扁平細胞層牥常に精細管の全周に発見さ れるから, 技そらく本細胞は, 多くの突起を出して腺房 を籠状に包む一般筋上皮細胞とは形態を異にし，一連の 薄板をなして精細管の全面を被うものと考えられる。

この細胞の胞体は極めて扁平で, 核より離れた部位で は 300〜 600m $\mu$ の厚さを示すに過ぎず，一方核の付近 に颃いてはや>厚みを増加する。胞体内には中心部特に 核の近辺に限局して粗面小胞体, 糸粒体抢よびゴルジ複 合体が認められる。これらの細胞小器官を含まぬ胞体辺 縁部内には, 図 3 に見られるように細胞の表面に平行に 走る太さ $5 \mathrm{~m} \mu$ 以下の繊細なフイラメントが充満し,との ため弱拡大下では, 胞体辺縁部は一見均質であるかの如 く観察される. 形質膜の内面に接して多数の pinocytic vesicles が発見され，また所々に図 1 に示されるような 電子密度の高い部分が見られる。

本細胞のむろ一つの特徵洁, 形質膜のすぐ周囲に薄い 基底膜を有することであり, この点固有の基底膜を持た ぬ線維芽細胞その他の結合組織性細胞とは, はなはだ容 易に区別される. 図 3 亿は隣接する 2 個の扁平細胞が示 されるが，との図に見られるように隣接細胞の形質膜間 には10〜15m $\mu$ のせまい間隚が介在するのみであり, 基 底膜は存在しない，なた稀には対面する形質膜直下に電 子密な物質の蓄積が認められるとともあつた（図 4 ).し かし一般上皮細胞淿怙けるような典型的なデスモゾーム は，発見できなかつた。な拈我くの観察したラット，マ ウスおよびイヌに掞いて，動物による細胞の微細構造の 違いは認められなかつた。

被膜組織の第 4 層をなす線維芽細胞は, 胞体辺縁部に 捛いても粗面小胞体に富久, また密集するフイラメント および固有の基底膜を所有しない. 従つて第 2 層の扁平 細胞乞の区別は容易である。な被膜内には，毛細管お よび神経線維证含まれていない。

\section{考 按}

上記のように，精細管は 1 㬝時に 2 層に配列する扁平 な細胞によつて, その全周を被われる. これら扁平細胞 の微細構造における特徴を要約すると次のようである.

1）形質膜に接し，てその外面に固有の基底膜を所有す る.
2）胞体内に細胞の表面に平行に走る繊細なフイラ メントの密集が見られる。

3）形質膜の直下に多数の pinocytic vesicles を認 め得る.

4）形質膜に接する胞体基質は所くで高い電子密度を 示す.

5）粗面小胞体, 糸粒体, コルジ複合体结, 胞体の中 央部特に核の近辺に限局して存在し，一方それ以外の部 分はすつぱら上記フイラメントに上り占められる。

以上の特徴虫いずれも平滑筋細胞のそれであり，従つ て扁平細胞证電顕形態学的に極內て平滑筋細胞に類似卞 るものということができる。しかしながら平滑筋細胞に くらべて胞体はょりはるかに扁平であり，また平滑筋細 胞に特有ないわゆる dense patch ${ }^{12)}$ を持をぬ点で典型 的な平滑筋細胞とは，多少その構造を異にしてている。

最近 Woodhouse and Rhodin ${ }^{13)}$ は, 動物の第 3 眼瞼 に見られる Harderian 腺について電顕的観察学行つた が, 彼らの記載する筇上皮細胞が, 精細管周囲の平滑筋 様細胞と非常に類似した微細構造を示すととは興味深 い.すなわち筋上皮細胞は前記 5 つの扁平細胞の特徵学 総て借え，しかも dense patch を所有しない。しかし ながらこの細胞虫多数の乫起を出して籠状に腺房を包を ものであるから, 電顕写真上では, 胞体の断面が腺房周 囲に所《不連続的に出現し，乙の点で精細管の平滑筋様 細胞とは相違している.ただし Leeson and Leeson? によれば，精細管の平滑筋様細胞す分化の途上では紡鏵 形ないし星形を呈するょうであるという。

Clermont ${ }^{5)}$ はラットの精細管周囲に，本研究で明ら かにされたものと同様の扁平細胞を発見し，乙れが収縮 能を持つもの々予湘した。.そして生きたラットの精細管 の収縮を直接顕微鏡下に観察し，とのととより本細胞が 精細管内に扮ける精子の移動に重要な役割を果すものと 考えた. Lacy and Rotblat ${ }^{6)}$ は同じくラットの精巣に 执いて同様の細胞を観察し，乙れらは扣そらく，一般の 平滑筋細胞とは分化の程度を異にする一種の平滑筋細胞 であろろと述べた。 Leeson and Leeson ${ }^{7}$ もまたット の精巣に平滑筋様細胞を認め，加成体に見られる被膜 組織の層構成が完成するのは, 生後22日目であるととを 明ら亦にした．今回の研究によつて，ラットのみならず マウス拉よびイヌに掞いても，等しく平滑筋類似細胞の 存在が確認されたのであるが，乙のととより本細胞が各 種哺乳動物に広く存在し, 従つて機能的にも重要なもの 
であるととが示唆されるであろう。

一般に精子は精細管内では自動性を持をず，その移動 はもつぱら受動的であるといわれているが，抬そらく本 細胞は收縮能を有し，それによつて精子の移動学助ける もの々思われる．ただしもし精子の移動に関係する収縮 性細胞であるとするならね゙当然自律神経支配を受けるも のと期待さ礼るが，多数の標本についての入念な観察に も亦からず，被膜組織内炕は全く神経線維を発見する ことができなかつた。

な抢近藤 ${ }^{12}$ は, ヒトの精栄間質の電顥観察に扮いて, 精細管を取り蛋く内皮様細胞について記載を行つを。彼 はこの細胞の詳細な構造, 抬よび線維芽細胞との相違を 明確にしていないが，拉そらく内皮㴍細胞の一部注本研 究で明らかにされた平滑筋類似細胞に相当するものと思 われる。

\section{䌊 括}

ラット, マウス抬よびイヌの精巣とついて, 精細管の 被膜組織内に平滑筋類似細胞の存在を明らかにし, その 電顥形態学的特徵を詳述した. 本細胞恃平面的に広がる 扁平な細胞で， 1 層時に 2 層の連続した薄層を形成してて 精細管の全周を完全に被つている. 胞体内には中心部特 に核の近辺に限局して粗面小胞体, 糸粒体拉よびゴルジ 複合体が含まれる。これらの小器官を持ため胞体辺縁部 は細胞の表面に平行に走る $5 \mathrm{~m} \mu$ 以下の太さのフイラメ ントの密集によつて占められる. 形質膜直下には,多数の pinocytic vesicles と, 末た所々に電子密度の高い部分 が認められる。形質膜のすぐ外面には薄い基底膜があつ て細胞奈包む。すなわち本細胞の微細構造は, 平滑筇お よび筋上皮細胞のそれと非常に類似して㧍り, 従つて本 細胞汇収縮能のあることが予想される。な扢神経線維の 被膜組織内への進入は認められなかつた。

稿を終るに当り, 御指導, 御校閲を賜つた恩師宾戸仙 太郎教授に哀心より感謝いたします。また, 本研究が東 北大学医学部第 2 解剖学教室で行われたことを記すと共 に, 絶えず実際面で御指尊を受けた山本敏行教授に深謝 いたします。

\section{写真説明}

1）少量の繊細な膠原線維を含む細胞間腔.

2）平滑笳類似の構造を示す扁平細胞.

3）少量の緎細な膠原線維を含む細胞間腔.

4）線維芽細胞.

$\mathrm{S} T$ ：精細管上皮，倍率はすべて16,500倍.

図1）精細管の被膜組織の層構成.

精細管上皮に接して基底膜（B）が見られる。扁平細
胞 (2) は細胞小器官に乏しく, 形質膜に接してその内 面に pinocytic vesicles 打よび電子密度の高まつた部 分（爪）を認める。（1）打よび（3）の細胞間腔には 瀻細な膠原線維が含まれる。最外側を占める線維芽細胞

（4）は 2 層に配列している.ラット，鉛染色.

図 2 ) 㾊平細胞の核周部.

小胞体, 系球体などの細胞小器官は核の近辺に限局し て存在する。胞体のその他の部分は均等な密度をるつて 分布する繊細なフイラメントによつて占められる. 形質 膜はや〉切線方向飞切られているため, 明瞭ではない が, その内面に接して存在する多数のpinocytic vesicles

（P）は明らかに観察される. ラット，鉛染色.

図 3 ) ラット精細管の被膜組織. 隣接する 2 個の扁 平細胞を示す.

両細胞は10〜 $15 \mathrm{~m} \mu$ のせまい間隙を隔てて密に相接し ている。胞体辺縁部に瀻細なフイラメント構造を見る。 $\mathrm{P}:$ pinocytic vesicles, $\mathrm{M}:$ mitochondrion. ウランー 鉛 2 重染色.

図 4) 2 個の扁平細胞の隣接部.

両細胞の形質膜直下に電子密な物質の蓄積を認める (爪). ラット，鉛染色.

因 5) イ邓の精細管被膜組織.

扁平細胞は 2 層に配列し( 2 拉よび 2 '), その間には缺 原線維を含むせまい間隙が介在する，B：基底膜, 鉛染 色.

\section{交 献}

1) Bloom and Fawcett: A Textbook of Histology, Eighth Edition, Philadelphia, London, p. $567,1962$.

2) Wolfgang Bargmann: Histologie und Mikroskopische Anatomie des Menschen 5. überarbeitete Auflage, Georg Thieme Verlag, Stuttgart, p. 580, 1964.

3) Stöhr, v. Möllendorff und Goerttler: Lehrbuch der Histologie und der mikroskopischen Anatomie des Menschen 28 Auflage, Veb Gustay Fischer Verlag, Jena, p 375, 1959.

4) Rhodin J.A.G.: An Atlas of Ultrastructure, W.B. Saunders Company, Philadelphia and London, p. 104, 1963.

5) Y. Clermont: Exp. cell Res, 15, 438, 1958.

6) Lacy, D. and J. Rotblat: Exp. cell Res., 21, 49, 1960.

7) Leeson, C.R. and Leeson, T.S. Anat. Re:. 147, 243, 1963.

8) Lacy, D.: Brit. med. Bull., 18, 205, 1962.

9) Millonig, G.: Fifth International Congress for Electron Microscopy, (s.s. Breese, Jr., editor) New York and London, Academic Press, Inc., 2, p. 8, 1962. 
10) Luft, J.H. : J. Biophysic and Biochem. Cytol., 9, 409, 1961.

11) Millonig, G.: J. Biophysic and Biochem. Cytol., 11, 736, 1961.

12) Choi, J.K.: Fifth international congress for electron microscopy, editted by Breese
S.S., Philadelphia M-9, 1962.

13) Woodhouse, M.A. and Rhodin, J.A.F.: J. Ultrastructure Res., 9, 76, 1963.

14）近藤猪一郎：日泌尿会誌，53，869, 1962 . （昭和 40 年 2 月 17 日受付） 